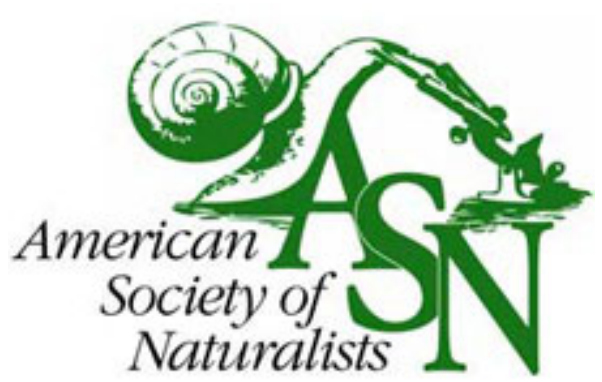

The Female of Eciton Sumichrasti Norton, with Some Notes on the Habits of Texan Ecitons Author(s): William Morton Wheeler

Source: The American Naturalist, Vol. 34, No. 403 (Jul., 1900), pp. 563-574

Published by: The University of Chicago Press for The American Society of Naturalists

Stable URL: http://www.jstor.org/stable/2453846

Accessed: 02-06-2015 16:46 UTC

Your use of the JSTOR archive indicates your acceptance of the Terms \& Conditions of Use, available at http://www.jstor.org/page/ info/about/policies/terms.jsp

JSTOR is a not-for-profit service that helps scholars, researchers, and students discover, use, and build upon a wide range of content in a trusted digital archive. We use information technology and tools to increase productivity and facilitate new forms of scholarship. For more information about JSTOR, please contact support@jstor.org. 


\title{
THE FEMALE OF ECITON SUMICHRASTI NORTON, WITH SOME NOTES ON THE HABITS OF TEXAN ECITONS. ${ }^{1}$
}

\author{
WILLIAM MORTON WHEELER.
}

ONE of the most interesting problems confronting the student of ant life in subtropical and tropical America is the determination of the sexual forms of the foraging, or driver, ants (Ecitonini). These ants are known only from a study of the workers, as the corresponding male and female forms, which are so aberrant as to have been placed in different genera, have not been satisfactorily determined in any one of the known species. The state of our knowledge of the sexes of the Dorylides (including the African species of Dorylini) up to I899 is summarized by Sharp in the Cambridge Natural History ${ }^{2}$ as follows:

The females of the Dorylides are amongst the rarest of insects and are also amongst the greatest of natural curiosities. Although worker and female ants are merely forms of one sex, - the female, - - yet in this subfamily of ants they have become so totally different from one another in size, form, structure, and habits that it is difficult to persuade one's self they can possibly issue from similar eggs. In the insect world there are but few cases in which males differ from females so greatly as the workers of Dorylides do from the females, the phenomena finding their only parallel in the soldiers and females of termites; the mode in which the difference is introduced into the life of the individuals of one sex is unknown. . . .

The specimens of female Dorylides that have been detected may, after fifty or sixty years of research, be counted on the fingers. As the greatest confusion exists in entomological literature owing to the forms of a single species having been described as two or three genera, the following summary of the principal names of genera of Dorylicles may be useful :

Eciton $=$ the workers $;$ Labidus = male $;$ o unknown.

Pseudodichthadia; female only known, possibly that of Eciton.

Chelionyrmex; workers and soldiers only known.

1 Contributions from the Zoölogical Laboratory of the University of Texas. Director W. M. Wheeler, No. 4.

2 Vol. vi, Pp. I79, ISo. 
Acnictus $=$ male $;$ Typhlatta $=$ worker $;$ unknown.

Rhogmus; male; female unknown (according to Emery the worker is very small and like Alaopone).

Anomma; only worker known; male probably a Dorylus.

Dorylus $=$ male $;$ Dichthadia $=q ;$ Alaopone and Typhlopone $=$ workers.

Until last year the only known insect that could be regarded as a female Eciton was the Pseudodichthadia, included in the above table. It was described by André as $P$. incerta in a paper which I have not seen. It has been supposed to be the female of Eciton omnivonum $\mathrm{Ol}$ (= cocum Latr.), " "but his

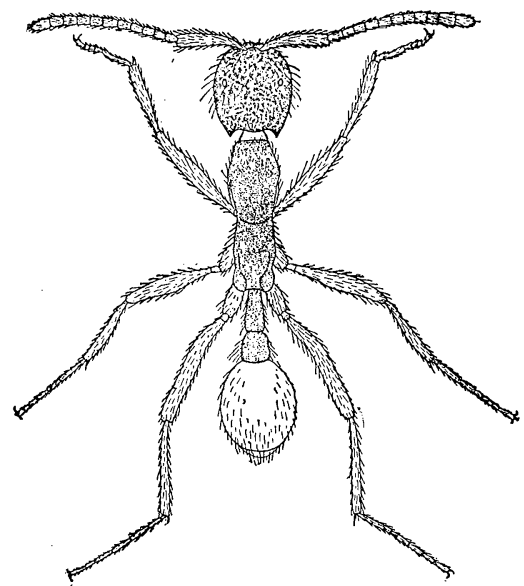

FIG. I. - Sterile female, or worker, of Eciton sumichrasti Norton (length $4.5 \mathrm{~mm}$.). description and figure are imperfect and do not greatly support his idea of a connection between Eciton and Pseudodichthadia.",2

Professor Forel, while on a visit to the United States during the summer of I899, discovered in North Carolina what is undoubtedly the female of Eciton carolinense Emery. He has drawn up a good description of the insect, but without a figure, in a letter to the Belgian Entomological Society. ${ }^{3}$ In this article and in a paper by Wasmann ${ }^{4} \mathrm{I}$ find mention of the fact that Schmitt had previously (I894) taken this insect in the same region.

For some months past I have been engaged in a study of the nests of the species of ants which abound in the vicinity of Austin, Texas, the locality of the classical studies of McCook

1 According to Emery (Beiträge zur Kenntnis der nordamerikanischen Ameisenfauna, Zool. Jahrb., Abth. f. System, etc., Bd. viii, p. 258) the male of this form is Labidas latreillei Jurine (= L. Sayi Haldem).

2 Sharp. Loc. cit., p. II 7 .

3 Ann. de la Soc. Entomol. de Belgique, tome xliii (1899), pp. 438-447.

4 Ein neuer Gast von Eciton carolinense, Deutsche Entomol. Zeitschr., Heft ii (1899), pp. 409, 410. 
on the agricultural ant (Pogonomymex barbatus. Smith). I had found several ${ }^{*}$ nests of Eciton omnivonum and E. sumichrasti under stones along the sloping banks of Shoal Creek, but in no case did these colonies comprise anything but workers, till quite unexpectedly, on the 3oth of March, in a large nest of the latter species, I detected what may be described in words borrowed from Forel's description of the female of $E$. carolinense: "une longue et large bête aveugle et aptère, se mouvant lourdement avec son immense abdomen distendu au milieu des $\breve{q} . "$ There could be no doubt that I had found the queen of the colony.

A few days later (April I I) one of my students succeeded in finding another large nest of E. sumichrasti containing an even larger female. In this nest some of the workers were carrying larvæe and pupæ, and the queen was still producing eggs. As this female differs in several particulars from the first one captured,

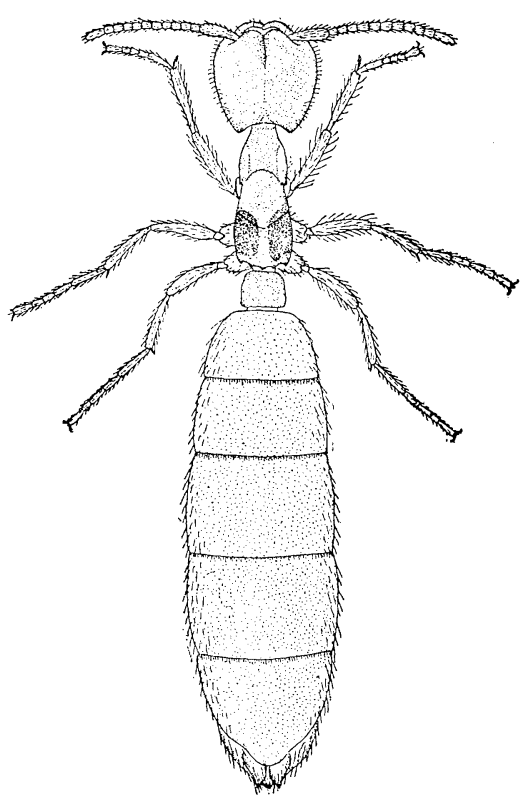

FIG. 2. - Young fertile female, or queen, of Eciton sumichrasti Norton.

I insert brief descriptions of both, designating the former specimen as $q A$, the latter as $q B$. Both of these insects had the head and thorax more or less concealed by shining yellow mites, shaped like minute chelomorph beetles, with long yellow hairs projecting from their dorsal surfaces. These mites, represented in situ in the sketch of $q B$ (Fig. 3), were sometimes either rapidly removed by the workers enveloping the queen or migrated of their own accord to the workers. I infer this from the fact that the queen would sometimes emerge from the swarm of workers glistening with these parasites, while at other times she would be found entirely free from them. 
$9 A$. Length $13.5 \mathrm{~mm}$. Light reddish brown, articulations of antennæ and legs and a large oblong blotch on either side of the metanotum, extending over the posterior third of the mesonotum, black. Surface of head, thorax, and abdominal pedicel subopaque, coarsely and rather densely punctate. Abdomen and legs shining, more finely and sparsely punctate. Body covered with delicate golden-yellow hairs, long on the legs and on the sicles and tip of the abdomen, short and erect on the head.

Head large, swollen, subcordate above the clypeus, broader in front than behind; posterior angles rather prominent, but not acute as in the worker. Eyes vestigial like those of the $\breve{q}$; ocelli absent. Mandibles slender, pointed, without distinct teeth. Down the middle of the head from the clypeus to the occiput runs a distinct furrow, deepest anteriorly. Antennal scape short, incrassated ; funicle consisting of subequal joints, except the last, which is twice as long as any of the preceding. Legs short, tibiæ and femora compressed antero-posteriorly. Thorax slender, elongate, without any traces of wings; suture between the pronotum and mesonotum faint but distinct, metanotum broader than the mesonotum, both flattened dorsally and distinctly impressed along the median line. Posterior surface of thorax declivous, bearing on each side near its lower posterior corner a small but distinct tooth. Abdominal pedicel consisting of a single node which is nearly square, being somewhat broader than long, with its anterior somewhat shorter than its posterior edge, flattened dorsally and with a slight longitudinal impression in the median line.

$q B$. Length $17 \mathrm{~mm}$. Dark rufous brown, legs somewhat lighter, black spots on the metanotum inconspicuous, with indistinct contours. Surface of the head, thorax, and abdominal pedicel more coarsely and confluently punctate than in $q A$; the mesothorax somewhat transversely wrinkled.

Head proportionally smaller than in $q A$. Furrow down the middle of the mesonotum and metanotum and the abdominal pedicel much deeper. Abdomen with the exception of the first segment greatly enlarged, so that the dorsal and ventral sclerites are separated from one another by the tense interscleritic membrane. This is thin and transparent, but appears milk-white owing to the underlying eggs. 
The differences between $q A$ and $q B$ seem to be clue to a difference in age, the former being a young queen, - possibly not more than a year old, - the latter a much older individual. If this supposition is correct, and if the differences above noted are constant, it is probable that the $q$ Eciton exhibits a certain amount of postmetamorphic growth even in the thoracic and basal abdominal regions.

The similarity of the $f$ Eciton to the African Dichthadia, the reputed female of Dorylus, will be apparent to any one who compares the accompanying figures with Emery's figure of Dichthadia. ${ }^{1}$ I also give a figure (Fig. I) of the worker of E. sumichrasti for the sake of showing the remarkable differences between the fertile and sterile forms of the same sex. The single node in the abdominal pedicel of the female and the two nodes in the worker, characters which are often used

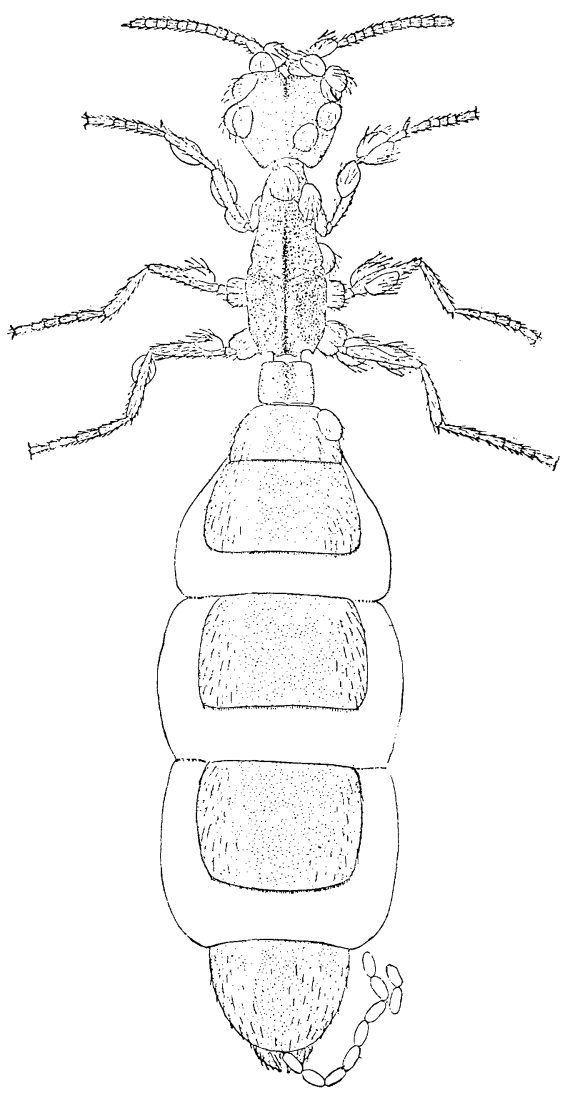

Fig. 3. - Old fertile female, or queen, of Eciton sumichrasti Norton, infested with mites. The insect was sketched during oriposition.

in the taxonomic separation of whole families of ants, are here combined, not only in the same species, but in the same sex $!^{2}$

${ }^{1}$ Reproduced in Sharp's contribution to the Cambridge Natural History, vol. vi, p. 178 , Fig. 79.

2 The discovery of a single node in the pedicel of the female Eciton strengthens the already strong probability that Labidus, also with a single node, is the bona fide male of this genus. 
The complete absence of any traces of wings in the female Dorylides also suggests many interesting problems for future investigation. The females must be fertilized either within the nest or during the organized marauding expeditions so characteristic of these ants.

Both the females in my possession were introduced at different times into an artificial nest (Janet pattern) of workers taken from an entirely different locality on Shoal Creek. They were very eagerly adopted and at once began to lay eggs. Female $A$ laid very few, but $q B$, as was to be expected, produced a great number. Some of the workers were always clinging, with signs of great agitation, to the tip of her abdomen, and as soon as an egg would appear on the shovel-like hypopygium it would be seized and carried to another part of the nest. To this same spot other eggs were brought for some time. Later, however, they were distributed in little packets and carried continually in the mandibles of the workers as these marched round and round the nest in files, two and three abreast. The eggs are of the same shape and color as those of Formica fusca, but smaller.

During the past year I have seen three species of Eciton in the vicinity of Austin: E. omnivonum Ol (= cocum Latr.), E. sumichrasti Norton, and what I take to be E. californicum Mayr. The last was taken only once by one of my students. Small colonies of E. omnivorum are not uncommon under stones, where they make burrows about a centimeter in diameter, usually leading directly into the ground. When the stone is lifted the ants show the greatest presence of mind (sit venia verbo!). They do not run about aimlessly and in disorder like other ants, but, notwithstanding the fact that they are absolutely blind, they at once organize themselves into columns and file down their burrows. The habits of this species thus appear to be the same as those of E. carolinense recently described by Forel (loc. cit., p. 444):

Leur faculté instinctive de se concerter et de former des files dépasse absolument tout ce que j'ai vu chez d'autres fourmis. Vous jetez une poignée d'Eciton avec leur larves sur un terrain absolument étranger. En pareille circonstance, où les autres fourmis s'éparpillent en désordre et ont besoin 
d'une heure ou plus (parfois moins) pour arriver à l'ordre, à réunir leur nymphes et surtout à reconnaître les environs, les Eciton se concertent, sans perdre une minute. En cinq minutes, ils ont formé des files distinctes de qui ne s'écartent pas les unes des autres, portent en partie les larves et les nymphes, et marchent en ligne assez précise, tâtant le terrain de leurs antennes, explorant tous les trous et fentes jusqu'à ce qu'elles trouvent une cavité à leur convenance. Alors le déménagement s'exécute avec un ordre et une rapidité étonnants. Les $\breve{q}$ se suivent et se comprennent, comme par mot d'ordre, et en bien peu de temps tout est en lieu sûr. Pas question de transport mutuel; c'est en plus précis le système des Tapinoma. Le fait est remarquable chez une fourmi aveugle, qui n'a absolument que ses antennes pour se diriger.

The colonies of E. sumichrasti are very much larger than those of E. omnivomun, and consist of thousands of individuals. They are found under large stones, often occupying cavities which they seem to dig themselves. They assemble in these cavities in compact masses, or swarms, which may be as large as a man's fist. These masses present a peculiar appearance, owing to the interlacing of the innumerable long, dark-red legs and antennæ, interspersed with the shining, lighter red abdomens. If such a mass be hastily scooped up and placed in a glass jar, the method of swarm formation may be watched at one's leisure. If the jar be held perpendicularly after being violently shaken till all the ants fall to the bottom, they will at once proceed to march up the sides of the jar in regular files. A few ants will soon come to rest, clinging to the glass, and will form the nucleus of a swarm which grows rapidly by additions from the moving columns. The ants are positively geotropic and therefore tend to hang head downwards when they cluster on one another. Such a swarm on the side of a jar is usually spindle-shaped, with perpendicular long axis. Frequently the swarm grows too large to be held in place by the claws of the individuals next to the glass, and the whole mass falls writhing to the bottom of the jar. The ants at once file up the walls of the jar and repeat the process. Occasionally the ants arriving at the top of the jar first will form the starting point for chains or festoons of ants, depending sometimes to a length of six inches in the form of a cord about a centimeter in diameter. In forming these chains, which remind 
one of the pictures of prehensile-tailed monkeys crossing a stream, the insects make good use of their long legs and hooked claws. These chains may persist for hours, but are more often soon broken as their weight increases. If some loose earth be placed in the bottom of the jar, the ants will be seen to carry little pellets of it in their mandibles as they file up the sides of the vessel and to use these as points of attachment for their feet and jaws during swarm formation. Termites placed in the jar are at once devoured. Their heads and other fragments of their bodies are afterwards used by the ants for the same purpose as the pellets of earth.

It is evident that $E$. sumichrasti possesses in a very marked degree the power of swarming so characteristic of certain tropical Ecitons. The nomadic habits which have been observed in these forms were not observed in E. sumichrasti. During the winter and spring months, at least, the Ecitons I have observed occupy the same nest. This they probably continue to do till their young are raised. Belt has given an interesting description of the wandering and swarming habits of E. hamatum in Nicaragua. ${ }^{1}$

The Ecitons are singular amongst the ants in this respect, that they have no fixed habitations, but move on from one place to another, as they exhaust the hunting grounds around them. I think Eciton hamata does not stay more than four or five days in one place. I have sometimes come across the migratory columns. They may easily be known by all the common workers moving in one direction, many of them carrying the larva and pupæ carefully in their jaws. Here and there one of the light-colored officers moves backward and forward directing the columns. Such a column is of enormous length, and contains many thousands if not millions of individuals. I have sometimes followed them up for two or three hundred yards without getting to the end.

They make their temporary habitations in hollow trees, and sometimes underneath large fallen trunks that offer suitable hollows. A nest that I came across in the latter situation was open at one side. The ants were clustered together in a dense mass, like a great swarm of bees, hanging from the roof, but reaching to the ground below. Their innumerable long legs looked like brown threads binding together the mass, which must have been at least a cubic yard in bulk, and contained hundreds of thousands of individuals, although many columns were outside, some bringing in

1 The Naturalist in Nicaragua, pp. 24-26. London, 1888. 
the pupæ of ants, others the legs and dissected bodies of various insects. I was surprised to see in this living nest tubular passages leading down to the center of the mass kept open just as if it had been formed of inorganic materials. Down these holes the ants who were bringing in booty passed with their prey. I thrust a long stick down to the center of the cluster, and brought out clinging to it many ants holding larvæ and pupæ, which probably were kept warm by the crowding together of the ants.

The workers of the Texan species of Eciton have a very disagreeable odor unlike that of other ants. It closely resembles the vile odor of the neuropteron Chrysopa. The females of E. sumichrasti, on the contrary, have a mild, pleasant odor.

The males of Eciton, formerly described as species of Labiclus, are frequently taken about the electric lights in dwellings and in the streets of Austin. I have seen three species, but two of these, from their size and coloration, can hardly belong to any of the above-mentioned species of Eciton, so that the workers of at least two more species have not yet been found in this vicinity. ${ }^{1}$

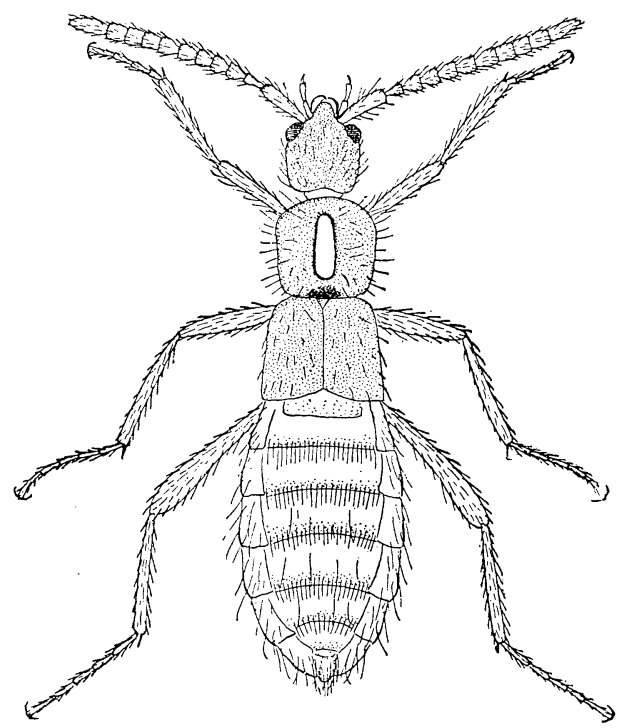

FIG. 4. - Ecitophilous staphylinid beetle occurring in the nest of Eciton sumichrasti Norton.

In conclusion some mention may be made of a few myrmecophiles encountered in the nests of Eciton. With E. omnivonum occurred a few specimens of a small histerid beetle (presumably Echinodes setiger Lec.). The peculiar ectoparasitic mite referred to above may also be included among the ecitophiles. Of greater interest is a small staphylinid beetle (Fig. 4), $2.75 \mathrm{~mm}$.

1 Cresson (Synopsis of the Hymenoptera of America, North of Mexico, Trans. Amer. Ent. Soc., Suppl. Vol., Phila. (IS87), p. 259) enumerates six species of Labidus as occurring in Texas. If these are really distinct species, there must be at least an equal number of species of Eciton in the State. 
long, which is so much like a small worker, Eciton sumichrasti, that I did not notice it in the artificial nest till the ants had been under my observation for a month! One morning I happened to see it as it was marching around the nest in the files of the Ecitons. The movements of its legs and antennæ were precisely like that of its hosts. This resemblance extends also to its size, coloration, and the character of the surface of its body. Its head, thorax, and elytra are opaque, dark red, rather irregularly punctate, and furnished with a few scattered hairs. The abdomen is smooth and shining, of a lighter red color, widened towards the tip, and covered with longer, denser hairs than the remainder of the body. The eyes are well developed. The antennæ show a decided resemblance to those of the ant. The most striking character, however, is a very deep, elongate elliptical depression in the middle of the pronotum. The bottom of this depression seems to be formed by a white membrane. It is difficult to assign a function to this singular structure, unless it be the orifice of a huge gland that may secrete some substance relished by the Ecitons. During life the broadened tip of the shining red abdomen is bent up after the manner of staphylinids, and the resemblance of the insect to a worker Eciton becomes even more striking.

Wasmann has given an excellent account of the ecitophilous Staphylinidæ of Brazil. ${ }^{1}$ In two more recent papers he describes a couple of staphylinids living with Eciton carolinense. ${ }^{2}$ In his former contribution Wasmann distinguishes a number of ecitophilous genera (Ecitomorpha, Ecitonides, Mimeciton, Ecitonilla), which comprise some very remarkable mimics of the Ecitons with which they live. The form taken by myself is probably the representative of a new genus and is an additional case of mimetic adaptation somewhat less perfect than the genera described by Wasmann. It is, nevertheless, an admi-

1 Die Ameisen- und Termitengäste von Brasilien, I. Theil, Verh.k.k. Zool. Zoot. Gesell. Wien. (Jahrg. I 895) pp. I-45, 7 Abbild.

2 Ein neuer Ecitongast aus Nord-Carolina, Deutsche Entomol. Zeitschr. (1897), Heft ii, pp. 280-282 ; and Ein neuer Gast von Eciton carolinense, Deutsche Entomol. Zeitschr. (1899), Heft ii, pp. 409, 410. The species are Ecitonusa Schmitti, Wasm. und E. Foreli, Wasm. 
rable illustration of the truth of some of Wasmann's remarks concerning these cases of mimicry. Since the Ecitons are blind, the color of the ecitophiles is of no consequence and may differ from that of the ants, - although in the present case there is great similarity even in coloration, - but the form and surface sculpture of the guest insect are of the greatest importance. Wasmann believes that the resemblance in sculpture between the staphylinids and their hosts - rough beetles living with the opaque species of Eciton, and smooth beetles with shining species of the ant - enables the former to prey on the eggs and larve of the Ecitons or to share their booty without being suspected as aliens. It is, incleed, quite probable that we have here a new and elsewhere unknown form of mimicry - a deception of the sense of touch which must be extraordinarily keen in these blind ants.

The University of Texas,

Austin, April 5, I900.

POSTSCRIPT.

Since the above account was written it has been possible to make a few additional observations of interest on our Texan Ecitons. The insect which I designated as $q B$ died May i $\$$, apparently of exhaustion, after depositing nearly all her eggs. $q A$ continued to live in the nest and to produce a few eggs from time to time. On April 20, when I disturbed the clustered workers, I was dumfounded to find them covering also another queen intermediate in length and coloration between $q A$ and $q B$ ! Now this queen, which may be called $q C$, could not possibly have existed as an insect larger than the largest workers $(4.5 \mathrm{~mm}$. long) among the thousand or more collected and placed in the artificial nest March Io. Soon after the colony was taken it was kept for about two weeks in a glass jar and had been the subject of numerous experiments on the clustering habit. A large insect, I $6 \mathrm{~mm}$. long and with shining white bands on the abdomen, could not have escaped my attention like the small mimetic ecitophile above described. Her presence in the colony can only be explained on the assumption that she was developed within the nest during less than a month from an insect closely resembling a worker in size and appearance. The workers must have been feeding her abundantly, notwithstanding their 
devotion to the two introduced queens. Careful comparison of the largest workers with the $q$ of $E$. sumichrasti will show that there is nothing transcending the possibilities of insect development in supposing that a worker could be developed into a queen. This could, perhaps, be accomplished by a certain amount of postmetamorphic growth with an ecdysis or two, but the differences are still too great to justify us in drawing this conclusion from circumstantial evidence. During the coming year it may be possible to solve this interesting problem suggested by the sudden appearance of o $C$ in an artificial nest.

In the beginning of May my artificial colony showed signs of demoralization and decay. The eggs laid by $q A$ and $q B$ had been devoured and the workers were dying rapidly. $\subsetneq A$ and $q C$ were killed and preserved May I2, as I had no hopes of raising the males.

Very recently I have succeeded in finding several colonies of Eciton omnivorum. One of these, discovered under some large stones May 4, was very large and flourishing, but it contained no queen, larvæ, or pupæ. There were, however, dozens of callow workers of different sizes. This may serve as a clue to finding the still unknown $q$ of this widely distributed species, since it indicates that the breeding season is earlier than that of E. sumichrasti - possibly in December or January.

E. sumichrasti was observed on the march May I. May 2 I saw a black Eciton (near E. Californicum, but probably undescribed) moving along a path in double and triple files. These dates are here recorded because they seem to indicate the time when the Ecitons leave their temporary winter quarters to resume their marauding expeditions.

Austin, May 20, I900. 